\title{
Growth and $\mathbf{N}$ and $P$ Absorption Capability of Pistia Stratiotes Cultured in the Inorganic Fertilizer Enriched Media
}

\author{
Kamaruddin Eddiwan ${ }^{1 *}$ Efawani $^{1}$ and Rizky Janatul Magwa ${ }^{1}$ \\ ${ }^{1}$ Laboratory of Aquatic Biology, Faculty of Fisheries and Marine, University of the Riau, Campus BinawidyaJln HR \\ Soebrantas, KM 12.5 KecamatanTampan, Pekanbaru City, Riau Province, 28293, Indonesia
}

Received: April 04, 2018; Accepted: May 17, 2018; Published: June 04, 2018

*Corresponding author: Kamaruddin Eddiwan, Laboratory of Aquatic Biology, Faculty of Fisheries and Marine, University of the Riau, Campus BinawidyaJln HR Soebrantas, KM 12.5 KecamatanTampan, Pekanbaru City, Riau Province, 28293, Indonesia, Tel: +6285265408159; E-mail: kamaruddineddiwan@gmail.com

\begin{abstract}
Pistia stratiotes are able to grow rapidly in culture medium given inorganic compounds. $P$. stratiotes cultured in a culture medium that has been given nitrates, phosphates and potassium (NPK) fertilizer. P. stratiotes cultured in a culture medium that has been given NPK fertilizer. A CRD with 5 concentrations of inorganic fertilizers tested, i.e. 0 (Co); 15 (T1); 20 (T2); 35 (T3); and 50 g / 10 L (T4). Observation of growth and decrease of the inorganic compound in culture medium was done 5 times, every 3 days. The results show that the best growth was identified in plants grown in T4. At the end of the experiment, $18.8 \mathrm{~g}$ BW with a daily growth rate was $17.9 \%$ of the baseline value of BW. On the 7th day of the experiment, the decrease was $0.187 \mathrm{mg} / \mathrm{L}$ (N) and $0.237 \mathrm{mg} / \mathrm{L}(\mathrm{P})$. So P. stratiotes were able to absorb relatively high $\mathrm{N}$ and $\mathrm{P}$ from water and use it for its growth.
\end{abstract}

Keywords: P. stratiotes; Growth; inorganic materials absorption;

\section{Introduction}

P. stratiotes is a species of water plants most commonly found in the public waters in Pekanbaru City, province of Riau, Indonesia. These aquatic plants usually grow in waters that have been polluted, especially those that contain a lot of organic waste, due to the large amount of disposal of food, household, market, and so on. The waste has resulted in an increase in the content of inorganic compounds in general waters. As a result, the content of inorganic compounds in general waters around the city of Pekanbaru to be high and this, in turn, will affect the balance of the ecosystem of public waters [11].

Based on reports from previous researchers, public waters in Riau province at this time have many that experienced pollution, mainly due to the inorganic and organic material into the water in excess. [19] States that the high content of inorganic compounds in the waters can affect the abundance of organisms, but for some organisms, such waters condition is still tolerable, although later there will be species dominance in the ecosystem

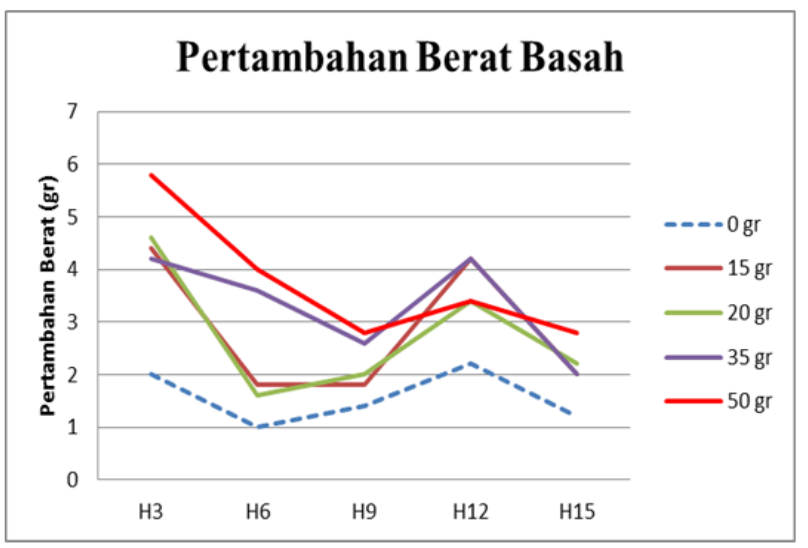

Figure 1: Test results on the change of wet weight due to the treatment of different organic materials during the study

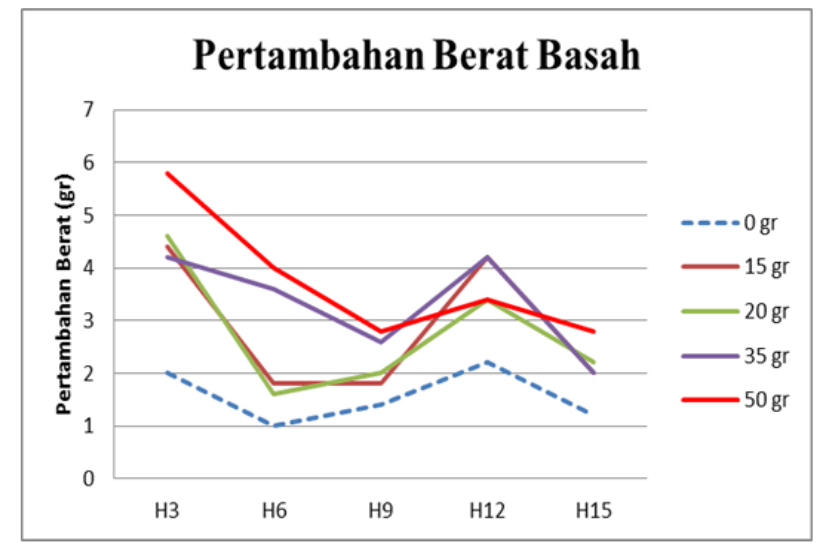

Figure 2: Test results on the growth of the number of petiole to the treatment of different organic materials during the experiment 
[21]. In an effort to control the imbalance of the ecosystem, and reduce the concentration of pollutants (organic and inorganic) in the common waters it can be done by utilizing the biological function of water plants, one of which can use P. stratiotes as phytoremediation [4].

The ability of $P$. stratiotes to decrease the content of organic and inorganic materials present in waters is very large and is environmentally friendly (Figure 2). The biological function of the P. stratiotes allows it to absorb the organic and inorganic compounds in the waters, and this capability varies greatly depending on the size of the plant [13]. One characteristic of hyper accumulator plants such as $P$. stratiotes is resistant to nutrients in high concentrations. Its root ability to absorb ground-based elements is quite high when compared to other aquatic plants, and it also has the capability of transplanting and accumulating organic and inorganic materials from root to tree canopy [14], $P$. stratiotes has the ability to directly absorb elements $\mathrm{C}, \mathrm{O}, \mathrm{H}$ from air, N, P, K, S, Ca, and Mg from pollutant and soil through their root organs [20], P. stratiotes ability to absorb organic and inorganic compounds are due to the process of ion movement between the cells and penetrate the cell membrane [15].

[19] Reported that the effect of feeding on fish pellets on the growth of $P$. stratiotes was able to reduce high ammonia levels in the waters. However, the study still does not explain the ability of $P$. stratiotes to absorb nutrients $\mathrm{N}$ and $\mathrm{P}$ is. In this connection, this experiment wanted to know clearly about the ability of $P$. stratiotes to absorb the nutrients ( $\mathrm{N}$ and $\mathrm{P}$ ).

\section{Materials and Methods}

This research was conducted in February - March 2018, and the experiment was conducted in Aquatic Biology Laboratory Faculty of Fisheries and Marine University of Riau. Testing of $P$. stratiotes on $\mathrm{N}$ and $\mathrm{P}$ was done by using a completely random design with 1 factor and 5 levels. Then the $\mathrm{pH}, \mathrm{DO}$ and temperature conditions during the experiment were observed.

\section{Experimental design}

In this experiment was used Completely Randomized Design. Treatment is an inorganic compound with 5 levels (dose 0, 15, $20,35,50$ gram), and repeated 5 times. Observations are made every 3 days for 15 days. (Figure 3) The observed responses were changes in root length $(\mathrm{cm})$, leaf $(\mathrm{mm})$, number of leaves (sheets/plants), new shoots (fruit), biomass (wet weight) and P. stratiotes ability to absorb nitrate and phosphate compounds in experimental media [15]. The experimental container uses a circular plastic jar. While the $P$. stratiotes test sample used was 7 grams' weight, which was cultured in water as much as $10 \mathrm{~L}$ per container, and on the bottom of the container was given 200 gram of soil substrate from the reservoir in public waters.

\section{Data analysis}

Data of measurement result of NO3, PO4, pH, temperature were analyzed descriptively. Daily growth rate calculator (LPH) $P$.

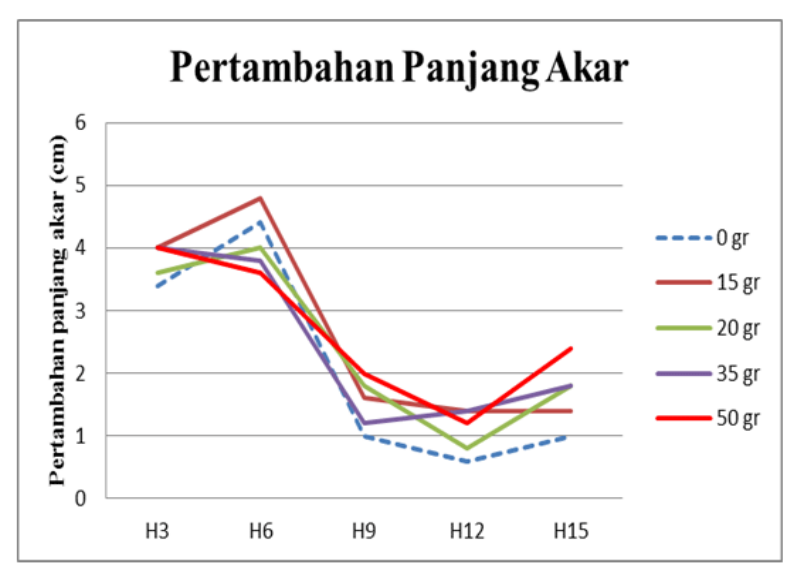

Figure 3: Test results on root length growth on the treatment of different organic materials during the experiment

stratiotes used the formula:

$$
\alpha=\frac{W_{t}-W_{0}}{t}
$$

Information:

$\alpha=$ Daily growth rate (gr / day)

$\mathrm{Wt}=$ final weight of $P$. stratiotes $(\mathrm{gr})$

WO = initial weight of $P$. stratiotes (gr)

$\mathrm{t}=$ length of maintenance (days)

The ability of $P$. stratiotes in absorbing organic compounds is calculated using the formula

$$
\text { Rate } P=\frac{\text { Nutrient early }- \text { Nutrient end }}{\text { T end }- \text { T early }}
$$

(Table 1) Meanwhile, to see the difference to the wet weight (biomass) it is used statistical analysis with the level of accuracy (significance) $\alpha=1 \%$.

\section{Results and Discussion}

\section{Water Plant Growth P. stratiotes}

\section{Biomass Increase}

From the experimental results, it is known that the highest growth of wet weight of $P$. stratiotes occurred at $50 \mathrm{~g}$ treatment with the average of 18.8-gram wet weight increase. (Table 2) At the 0 -gram treatment is known to be very slow growth with an average of $7.8 \mathrm{~cm}$. (Figure 1) The height of this wet weight growth is due to absorption of $\mathrm{N}$ and $\mathrm{P}$ elements from the culture medium so that it affects growth and is very good for the growth of $P$. stratiotes. Idris (2014), the increase of biomass in aquatic plants can occur due to the presence of luxury consumption which is marked by the decrease of nutrients in the waters. Excessive Luxury consumption is a common response to water plants in accumulating $\mathrm{N}$ and $\mathrm{P}$ elements higher than normal and used for 
Table 1: A description of the difference in wet weight due to the effect of different treatments of organic matter on the day of the experiment

\begin{tabular}{|c|c|c|c|c|c|}
\multirow{2}{*}{ Test length (days) } & \multicolumn{5}{|c|}{ The treatment of organic matter (g) } \\
\cline { 2 - 6 } & $\mathbf{P}_{\mathbf{0}}$ & $\mathbf{P}_{\mathbf{1 5}}$ & $\mathbf{P}_{\mathbf{2 0}}$ & $\mathbf{P}_{\mathbf{3 5}}$ & $\mathbf{P}_{\mathbf{5 0}}$ \\
\hline 1 & 7 & 7 & 7 & 7 & 7 \\
\hline 3 & 9 & 11.4 & 11.6 & 14.2 & 12.8 \\
\hline 9 & 10 & 13.2 & 13.2 & 17.4 & 19.8 \\
\hline 12 & 11.4 & 15 & 15.2 & 21.6 & 23 \\
\hline Total & 13.6 & 19.2 & 18.6 & 23.6 & 25.8 \\
\hline
\end{tabular}

Table 2a: The test results on the average length of the total number of petiole due to the treatment of different organic materials during the experiment

\begin{tabular}{|c|c|c|c|c|c|c|}
\hline \multirow{2}{*}{$\begin{array}{c}\text { The treatment of organic } \\
\text { matter }\end{array}$} & \multicolumn{7}{|c|}{ Day of the test } & $\mathbf{1 2}$ & $\mathbf{1 5}$ \\
\cline { 2 - 8 } & $\mathbf{1}$ & $\mathbf{3}$ & $\mathbf{6}$ & $\mathbf{9}$ & 3 & 3 \\
\hline $\mathbf{P}_{\mathbf{0}}$ & 0 & 0.8 & 1.4 & 4.2 & 4.8 & 6.8 \\
\hline $\mathbf{P}_{\mathbf{1 5}}$ & 0 & 1.6 & 3 & 4.2 & 5.8 & 7.6 \\
\hline $\mathbf{P}_{\mathbf{2 0}}$ & 0 & 1.4 & 3 & 5.2 & 6.2 & 7.6 \\
\hline $\mathbf{P}_{\mathbf{3 5}}$ & 0 & 1.4 & 3.6 & 4 & 5.6 & 7.8 \\
\hline $\mathbf{P}_{\mathbf{5 0}}$ & 0 & 1.4 & 3 & & \\
\hline
\end{tabular}

Table 2b: Experimental results of giving different organic materials to the range of stalk growth on P. Striotes

The treatment of organic matter

\begin{tabular}{|c|c|}
\hline matter & \\
\hline $\mathbf{P}_{\mathbf{0}}$ & \\
\hline $\mathbf{P}_{15}$ & \\
\hline $\mathbf{P}_{20}$ & \\
\hline $\mathbf{P}_{35}$ & \\
\hline $\mathbf{P}_{50}$ & \\
\hline
\end{tabular}

growth, as a form of food reserves to support its growth activity [18].

\section{Added New Shoots}

The result of the measurement of the new shoot increase is known to increase the most shots occur on the 15th day (5-12 shoots) and at least occur on day 3 (1-2 shoots). Many of its new buds are caused by growth activity as a result of the absorption of organic compounds present in the culture medium. (Table 3) While the small shoots are caused at the time of the 3rd day the plant is still adaptable and the energy obtained from organic compounds is still used for the growth of leaves and other organs, and yet for shoot formation. Where the increase of inorganic compounds on the test medium tends to increase the new shoots in the P. stratiotes [13]

The highest number of shoots was found in the $50 \mathrm{~g}$ treatment with a shoot-increase range of 4-11 fruit/plants. The treatment
Day of the test

\begin{tabular}{|c|c|c|c|}
\hline $\mathbf{6}$ & $\mathbf{9}$ & $\mathbf{1 2}$ & $\mathbf{1 5}$ \\
\hline $2-4$ & $2-4$ & $2-4$ & $2-4$ \\
\hline $3-5$ & $2-7$ & $3-9$ & $5-12$ \\
\hline $2-5$ & $3-8$ & $3-10$ & $3-10$ \\
\hline $2-5$ & $3-7$ & $3-9$ & $3-12$ \\
\hline
\end{tabular}

of inorganic compound $0 \mathrm{~g}$ is the least shoot growth (0-4 fruits/ plant), and this new shoot comes from stolen. A stolen is more formed on test media containing nutrients. Bey (2007), more stolen is formed on the test water which contains many nutrients (inorganic material) in high concentration so that the number of tillers produced more and more. The formation of saplings in plants $P$. stratiotes derived from stolen.

Rijal (2014), P. stratiotes is a plant that can breed not only generatively through pollination on flowers, but also vegetative. Breeding can be done because it is able to form stolen. (Table 4) The stolen can be cut off at the end and will break off and grow into a new individual. Rao, PN, and Reddy, USA (1984) stated that this water plant can develop rapidly, because it can be done with generative and also vegetative by using stolen so that with the ability, the plant can grow and can expand and form big colony that can cover the entire surface of the waters available to them [6]. 
Table 3: Test results on root length growth on the treatment of different organic materials during the experiment

\begin{tabular}{|c|c|c|c|c|c|}
\hline \multirow[b]{2}{*}{ Test length (days) } & \multicolumn{5}{|c|}{ The treatment of organic matter $(\mathrm{g})$} \\
\hline & $\mathbf{P}_{0}$ & $\mathbf{P}_{15}$ & $P_{20}$ & $\mathbf{P}_{35}$ & $\mathbf{P}_{50}$ \\
\hline 0 & 18.2 & 18.4 & 18.4 & 18.2 & 18.4 \\
\hline 3 & 21.6 & 22.4 & 22 & 22.2 & 22.4 \\
\hline 6 & 26 & 27.2 & 26 & 26 & 26 \\
\hline 9 & 27 & 28.8 & 27.8 & 27.2 & 28 \\
\hline 12 & 27.6 & 30.2 & 28.6 & 28.6 & 29.2 \\
\hline 15 & 28.6 & 31.6 & 30.4 & 30.4 & 31.6 \\
\hline Total & 10.4 & 13.2 & 12 & 12.2 & 13.2 \\
\hline Percentage (\%) & 57 & 72 & 65 & 67 & 72 \\
\hline
\end{tabular}

Table 4: The results of the test on the increase of leaf number on the treatment of different organic materials during the experiment

The treatment of organic

\begin{tabular}{|c|c|c|}
\hline $\begin{array}{c}\text { The treatment of organic } \\
\text { matter }\end{array}$ & & $\mathbf{0}$ \\
\cline { 3 - 3 } & & 5.4 \\
\hline $\mathbf{P}_{\mathbf{0}}$ & Average & $5-6$ \\
\hline $\mathbf{P}_{\mathbf{1 5}}$ & Range & 5.4 \\
\hline & Average & $5-6$ \\
\hline $\mathbf{P}_{\mathbf{2 0}}$ & Range & 5.4 \\
\hline & Average & $5-6$ \\
\hline $\mathbf{P}_{35}$ & Range & 5.2 \\
\hline & Average & $5-6$ \\
\hline $\mathbf{P}_{\mathbf{5 0}}$ & Range & 5.2 \\
\hline & Average & $5-6$ \\
\hline
\end{tabular}

\section{The growth of Root Length}

The measurements on the longest root growth length of roots are $31.6 \mathrm{~mm}$ and the mean of $22 \mathrm{~mm}$. This longest root addition is due to the ability of $P$. stratiotes to absorb the organic compounds optimally. While the shortest root growth occurs because in concentrations 20 and 35 the P. stratiotes cannot absorb organic compounds optimally. Sridhar, (1986), the tendency that increased doses of inorganic compounds on test media will prolong the growth in the root of water plants $P$. stratiotes. $\mathrm{N}$ nutrient elements will be absorbed through the roots first by water plants P. stratiotes for the sake of growth [19].

At the $50 \mathrm{~g}$ treatment known to occur the largest growth of root length, with a total average growth of $13.2 \mathrm{~cm}$ while the longest root length growth is on the treatment of $0 \mathrm{~g}$ inorganic compounds with a total growth rate of $10.4 \mathrm{~cm}$. (Figure 8) This can happen because the elements of nitrate and phosphate in the test medium affect root growth in plants. Sitrabio (2012), the function of phosphorus (P) elements for plants is for root growth, flowering, ripening fruit/ seed/grain. (Table 5) The P element

\section{Test length (days)}

\begin{tabular}{|c|c|c|c|c|}
\hline $\mathbf{3}$ & $\mathbf{6}$ & $\mathbf{9}$ & $\mathbf{1 2}$ & $\mathbf{1 5}$ \\
\hline 7 & 9 & 10.4 & 11.6 & 12.4 \\
\hline $6-8$ & $9-12$ & $9-12$ & $11-12$ & $11-13$ \\
\hline 7.2 & 9.2 & 11.2 & 12 & 13 \\
\hline $6-8$ & $8-10$ & $10-12$ & $11-13$ & $12-14$ \\
\hline $6-7$ & 8.2 & 10.2 & 11.6 & 13 \\
\hline 6 & $7-10$ & $9-12$ & $10-12$ & $12-14$ \\
\hline $5-7$ & 7.6 & 9.4 & 10.4 & 12 \\
\hline 6.8 & $6-9$ & $8-10$ & $9-12$ & $10-14$ \\
\hline $6-7$ & 8.4 & 10 & 10.8 & 12.2 \\
\hline
\end{tabular}

also serves for the preparation of cell nuclei, fats, and proteins. In addition, $\mathrm{P}$ element also serves to stimulate the defense of plant cells and enlarge cell tissues [15].

The treatment of inorganic compounds with a dose of 50 $\mathrm{g}$ has the longest root growth. This is caused by aquatic plants of $P$. stratiotes using $\mathrm{N}$ nutrients in test medium for root length growth. Walstad (2007) explains that many N compounds in the waters will be able to accelerate the growth of roots but also can damage the plant because it can be toxic to the roots. Water plants P. stratiotes utilize the excess of $\mathrm{N}$ elements in the test medium for root growth [20].

\section{Increase in Number of Leaves}

The highest number of leaves was found in the treatment of inorganic compound $35 \mathrm{~g}$ with a leaf range of 10-14 sheets/plant. While the least leaf growth is found in the treatment of $0 \mathrm{~g}$ with a leaf range of 11-13 sheets/plant. In the treatment of inorganic compound, $35 \mathrm{~g}$ is the highest leaf addition. This occurs because of the presence of excess nitrogen elements in the treatment of 
Table 5: Experimental results on the treatment of different organic matter to the leaf length (mm) during the study

\begin{tabular}{|c|c|c|c|c|c|}
\hline \multirow{2}{*}{ Test length (days) } & \multicolumn{5}{|c|}{ The treatment of organic matter $\mathbf{g}$. } \\
\cline { 2 - 6 } & $\mathbf{P}_{\mathbf{0}}$ & $\mathbf{P}_{\mathbf{1 5}}$ & $\mathbf{P}_{\mathbf{2 0}}$ & $\mathbf{P}_{\mathbf{3 5}}$ & 29.1 \\
\hline 0 & 31.2 & 29.7 & 30.3 & 31.1 & 32.6 \\
\hline 3 & 32.5 & 32.1 & 32.3 & 33.9 & 34.1 \\
\hline 6 & 34.5 & 35.9 & 34.9 & 36.3 & 40.2 \\
\hline 9 & 36.2 & 38.7 & 38.2 & 37.7 & 41.2 \\
\hline 12 & 37.6 & 40.5 & 39.6 & 39.8 & 42.9 \\
\hline 15 & 38.7 & 42.1 & 41.2 & 10.5 & 10.3 \\
\hline Total & 7.4 & 12.3 & 10.9 & 36 & 35 \\
\hline
\end{tabular}

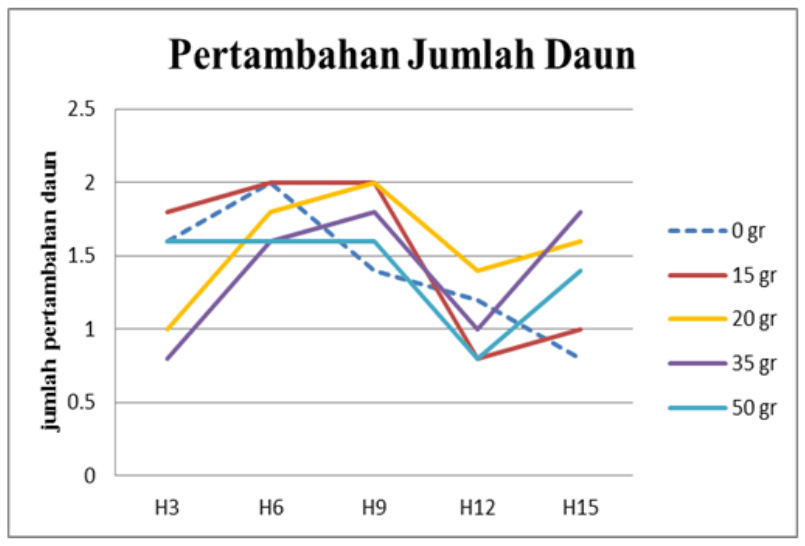

Figure 4: The results of the test on the increase of leaf number on the treatment of different organic materials during the experiment

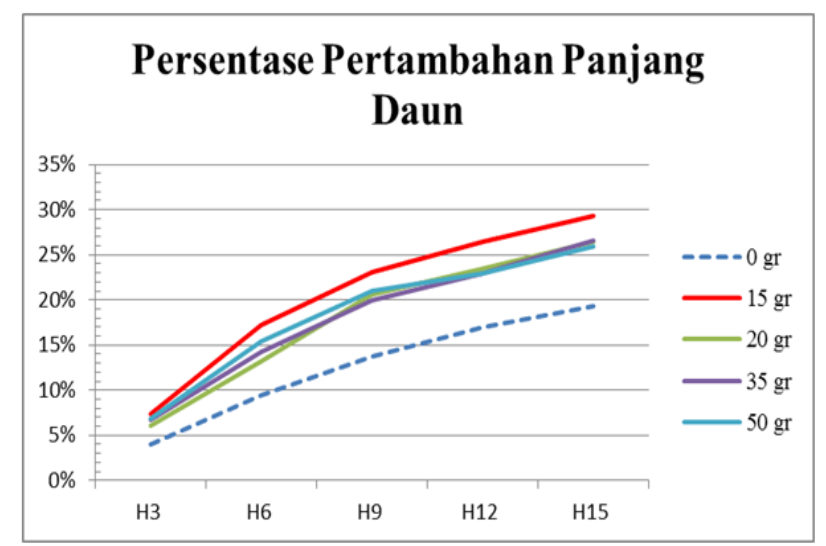

Figure 5: Experimental results on the treatment of different organic matter to the leaf length $(\mathrm{mm})$ during the study

inorganic compounds 35 gr. Sitrabio (2012), nitrogen function for plants is for vegetative growth (to enlarge, enhance, and green the leaves), and nitrogen also serves to arrange chlorophyll and leaves. Lack of nitrogen elements will cause the plant will experience slow growth/dwarf. The leaves will be yellowish- green, the size of the leaves narrow or small, and the leaves will quickly fall. (Figure 4) Leaf number growth is one of the vegetative growth parameters for $P$. stratiotes [14].

(Figure 5) Leaf growth is more likely to grow in high concentrations of inorganic compounds so that the number of leaves produced is also more numerous, but the number of leaves decreases with increasing dose of inorganic compounds on the test media, there has been a change of inorganic compounds into glutamine (Warsono and Sigit, 2001), In the test medium, the ammonium changes into glutamine that takes place rapidly in the leaves will accelerate the formation of new leaves. The impact will be the number of leaves that many in a relatively short time.

\section{Daily Growth Rate}

(Figure 6) The percentage of daily growth of $P$. stratiotes on the treatment of several doses of inorganic compounds showed that the fastest daily growth occurred at $50 \mathrm{~g}$ treatment, with the growth of $18 \%$ per day. While at $0 \mathrm{~g}$ showed very slow growth (7.5\% per day) Very slowly this growth is due to differences in the level of inorganic compounds given to the P. stratiotes Besides environmental factors such as turbidity, temperature, and availability of nutrients in the water, can have an effect on water plants [24-38].

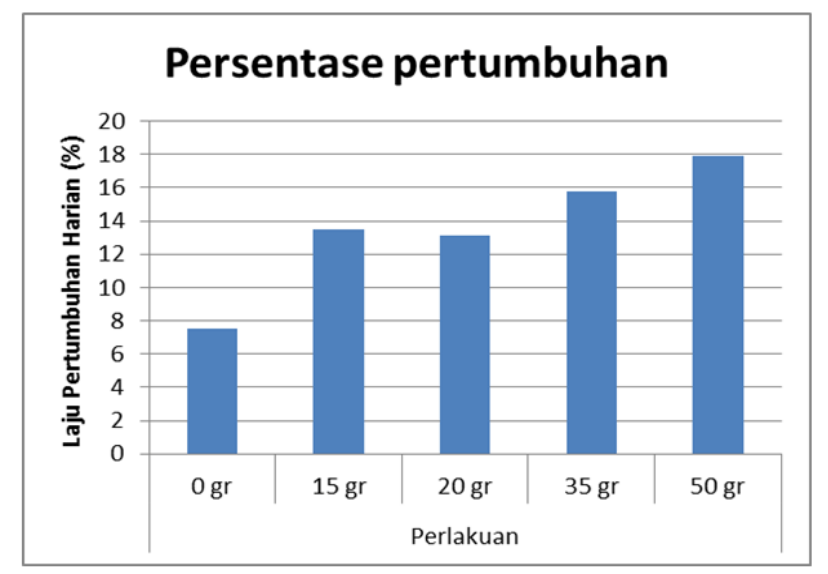

Figure 6: Percentage of Growth 


\section{Influence of Inorganic Compound Growth on Growth}

Based on the result of variance analysis test with SPSS application ver.17, at $35 \mathrm{~g}$ and $50 \mathrm{~g}$ of the inorganic compound showed the very real difference (Ho rejected, $\mathrm{F}$ arithmetic $<\mathrm{F}$ table). (Table 6) The accepted hypothesis is that alleged inorganic compounds dissolved in the culture medium affect the growth of $P$. stratiotes. The administration of inorganic compounds in $P$. stratiotes showed the very different effect on the treatment of 35 g and $50 \mathrm{gr}$.

Table 6: The average daily growth measurements on the treatment of different organic materials during the study

\begin{tabular}{|c|c|c|c|c|c|}
\hline Measurement & \multicolumn{5}{|c|}{ Treatment } \\
\hline & $\mathbf{P}_{\mathbf{0}}$ & $\mathbf{P}_{\mathbf{1 5}}$ & $\mathbf{P}_{\mathbf{2 0}}$ & $\mathbf{P}_{\mathbf{3 5}}$ & $\mathbf{P}_{\mathbf{5 0}}$ \\
\hline Daily growth (gr/Hari) & 0,52 & 0,95 & 0,92 & 1,1 & 1,25 \\
\hline Percentage (\%) & 7,5 & 13,5 & 13,1 & 15,8 & 17,9 \\
\hline
\end{tabular}

Absorption of $P$. stratiotes Water Plant on Nutrients (N and P)

Absorption of water plants $P$. stratiotes most drastically decreased i.e. until the day of 7 (middle), with the absorption of $\mathrm{N}(0.122 \mathrm{mg} / \mathrm{L})$ and $\mathrm{P}(0.054 \mathrm{mg} / \mathrm{L})$. After the 7 th day until the 15th shows the elements of $\mathrm{N}$ and $\mathrm{P}$ increase again, because on observation day 9 and 12 shows the leaves of dead water plants and roots that fall into the bottom of the water. The leaves that fall to the bottom of these waters will become the envelope of nutrients in the culture medium. In addition, $P$. stratiotes also decreased in growth, ranging from growth of weight and root length because $P$. stratiotes have reached maximum absorption on the 7th day. Increased morphological size of $P$. stratiotes is due to its ability to absorb nutrients in the water medium used for its growth. Nutrients that are needed in sufficient quantities for plants are $\mathrm{N}$ and $\mathrm{P}$. Other very important elements are $\mathrm{K}$,
$\mathrm{Ca}, \mathrm{Mg}$, and $\mathrm{S}$. This is possible because each plant has different capabilities to absorb and translocate nutrients [5]. In addition, each test plant has a maximum limit of nutrient absorption of different elements, so that when the nutrient absorption of plants to nutrients has reached the maximum limit, how much nutrients that exist in the planting medium, the plant will not absorb again [3].

(Table 7) Plants derive the ingredients necessary for growth through the roots by absorbing water from the surrounding environment by isotonic means. Roots also absorb minerals along with water absorption [7]. The transport of water and mineral salts is carried out by absorption by root cell cells, after passing through the root cells, which dissolves into the wood vessels (xylem) and then there will be vertical transport from root to stem to leaf, then taken to all parts of the plant by plant tissues ie phloem [10].

\begin{tabular}{|c|c|c|c|c|c|c|c|}
\hline \multirow[t]{2}{*}{ Nutrient } & \multirow[t]{2}{*}{ Time } & \multicolumn{5}{|c|}{ The treatment of organic matter (g) } & \multirow[t]{2}{*}{ Mean } \\
\hline & & $\mathbf{P}_{0}$ & $\mathbf{P}_{15}$ & $\mathbf{P}_{20}$ & $\mathbf{P}_{35}$ & $\mathbf{P}_{50}$ & \\
\hline \multirow[t]{5}{*}{ Nitrate } & Early & 0,0958 & 0,1479 & 0,1792 & 0,2313 & 0,1688 & \\
\hline & Central & 0,0125 & 0,0646 & 0,0542 & 0,0438 & 0,0333 & \\
\hline & End & 0,1276 & 0,1792 & 0,2729 & 0,5021 & 0,3979 & \\
\hline & Decrease & 0,0833 & 0,0833 & 0,1250 & 0,1875 & 0,1355 & $\begin{array}{c}0,1229 \\
(75 \%)\end{array}$ \\
\hline & Rate of decline & 0,0119 & 0,0119 & 0,0178 & 0,0267 & 0,0193 & 0,0176 \\
\hline \multirow[t]{5}{*}{ Phosphate } & Early & 0,3319 & 0,3540 & 0,4425 & 10,841 & 11,261 & \\
\hline & Central & 0,2367 & 0,4403 & 0,5465 & 0,8473 & 0,9934 & \\
\hline & End & 0,6546 & 0,7965 & 0,8031 & 19,496 & 22,898 & \\
\hline & Decrease & 0,0952 & 0,0863 & 0,1040 & 0,2368 & 0,1327 & $\begin{array}{c}0,0548(20 \\
\%)\end{array}$ \\
\hline & Rate of decline & 0,0136 & 0,0123 & 0,0148 & 0,0338 & 0,0189 & 0,0078 \\
\hline
\end{tabular}

(Figure 9) shows that the more roots absorb the nutrients the darker the root color of the P. stratiotes. [3] On root morphological observation, it is known that $P$. stratiotes roots begin to change color at the observation interval where the roots of plants are reddish or brown so that the petals are finally released from the stem. This happens because the root of $P$. stratiotes is part

of the plant that first interacts directly with the water media, so that the root organ will be quickly damaged compared to other organ parts of the plant in response to toxins from outside the plant body especially for aquatic plants [3]. In addition, the longer phytoremediation time also showed a change in the color of leaves that began to look yellowish green and in some plants appeared 


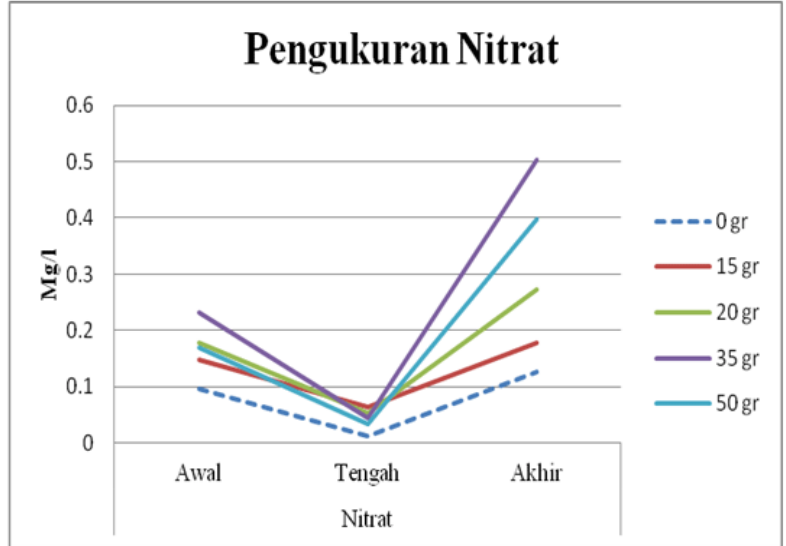

Figure 7: The result of measurement of nitrate compound content in culture medium during the study

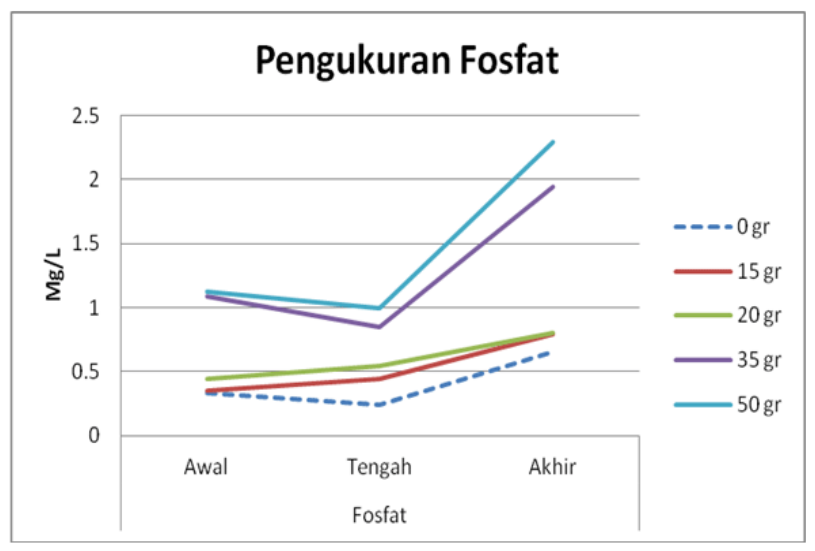

Figure 8: The result of measurement of phosphate compound content in culture medium during the study new shoots. Furthermore, Haslam in Hermawati (2005) states that leaf color changes to yellowish in some species can be caused by contamination of organic matter. The growth of new roots and buds may be the way plants survive [2]

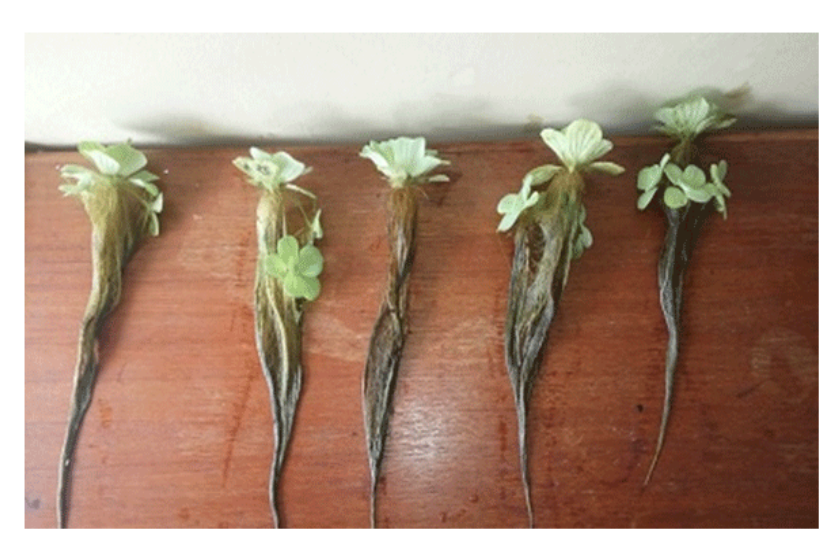

Figure 9: Test samples and differences in root length of $P$. stratiotes due to the effect of different treatments of organic matter during the study

\section{Water Quality in Culture Media}

Measurements of supporting parameters such as temperature and $\mathrm{pH}$ are performed to determine environmental conditions that can support the growth of water plants $P$. stratiotes. Research results on water quality parameters can be seen in (Table 8). Based on (Table 8) it can be seen that the increase in $\mathrm{pH}$ value at the end of observation is caused by photosynthesis of water plants P. stratiotes. Mara in Priyono (2007), that in the process of photosynthesis intensive (daytime), free $\mathrm{CO} 2$ in water will be used up under these conditions, bicarbonate (HCO3) converts to $\mathrm{CO} 2$ and ions of $\mathrm{OH}+[22]$ the dominance by these hydroxyl ions results in increased $\mathrm{pH}$ in the waters [16].

\begin{tabular}{|c|c|c|c|c|c|c|}
\hline \multirow{2}{*}{ Waters Parameter } & \multirow{2}{*}{ Time } & \multicolumn{5}{|c|}{ The treatment of organic matter (g) } \\
\hline & & $\mathbf{P}_{0}$ & $\mathbf{P}_{15}$ & $\mathbf{P}_{20}$ & $\mathbf{P}_{35}$ & $\mathbf{P}_{50}$ \\
\hline & Early & 29 & 29 & 29 & 29 & 29 \\
\hline \multirow[t]{3}{*}{ Temperature } & Central & 28 & 28 & 28 & 28 & 28 \\
\hline & End & 28 & 28 & 28 & 28 & 28 \\
\hline & Early & 6 & 6 & 6 & 6 & 6 \\
\hline \multirow[t]{3}{*}{$\mathrm{pH}$} & Central & 6 & 6 & 6 & 6 & 7 \\
\hline & End & 6 & 6 & 7 & 7 & 7 \\
\hline & Early & 0,0958 & 0,1479 & 0,1792 & 0,2313 & 0,1688 \\
\hline \multirow[t]{3}{*}{ Nitrate } & Central & 0,0125 & 0,0646 & 0,0542 & 0,0438 & 0,0333 \\
\hline & End & 0,1276 & 0,1792 & 0,2729 & 0,5021 & 0,3979 \\
\hline & Early & 0,3319 & 0,3540 & 0,4425 & 1,0841 & 1,1261 \\
\hline \multirow[t]{2}{*}{ Phosphate } & Central & 0,2367 & 0,4403 & 0,5465 & 0,8473 & 0,9934 \\
\hline & End & 0,6546 & 0,7965 & 0,8031 & 1,9496 & 2,2898 \\
\hline
\end{tabular}


The value of $\mathrm{N}$ and $\mathrm{P}$ analysis on the test media showed that on the 7th day experienced a drastic decrease due to rapid absorption by water plants $P$. stratiotes. Absorption of $\mathrm{N}$ and $\mathrm{P}$ is used of aquatic plants for the growth of these aquatic plants [19]. After the 7th day of $\mathrm{N}$ and $\mathrm{P}$ again rises due to the introduction of new organic matter from loose leaves According to Idris (2014), the presence of fluctuating nitrate in test media is a combination of dispersion by aquatic plants and the process of nitrification of ammonia and nitrite (Figure 7) . This is thought to occur because of the absorption of ammonia by low water plants and the ammonia undergoes a nitrification process that produces nitrate [12].

\section{Conclusion}

The growth of $P$. stratiotes in culture medium given inorganic compounds shows the growth of water plants biologically. The longest leaf growth and the fastest number of leaves occur in the treatment of inorganic compounds $15 \mathrm{gr} / 10 \mathrm{~L}$ of water. In the treatment of inorganic compounds, $50 \mathrm{gr} / 10 \mathrm{~L} \mathrm{can}$ affect the weight gain of wet, root length, and new shoots. The fastest daily growth is in the 50 gr treatment, with the growth of $18 \%$ per day. The result of statistical analysis showed that the effect was very different from the inorganic compound treatment of $35 \mathrm{~g}$ and 50 g / $10 \mathrm{~L}$ water.

P. stratiotes were able to decrease $\mathrm{N}$-nutrient $\mathrm{N}$ by $75 \%$ from initial nitrate and decrease of nutrient $\mathrm{P}$ by $20 \%$ up to day 7 (centre). After the 7 th day the water plants of $P$. stratiotes must be removed from the waters, otherwise, the nutrients in the water will again increase due to the ingress of nutrients from the $P$. stratiotes plant. Based on the results of the research, $P$. stratiotes showed nutrient uptake which is the result of decomposition of organic matter characterized by increasing biomass. Therefore, water plants $P$. stratiotes can be utilized as a nutrient absorbent nutrient ( $\mathrm{N}$ and $\mathrm{P}$ ) phytoremediator in the waters.

\section{References}

1. Abbasi SA, Nipaney PC, Panholzer MB. Biogas production from the aquatic weed Pistia (P. stratiotes). Bioresource Technology. 1991;37(3):211-214.

2. Das S, Goswami S, Talukdar A. A study on cadmium phytoremediation potential of water lettuce, P. stratiotes L. Bulletin of Environmental Contamination and Toxicology. 2014;92(2):169-174.

3. Dewi RK, Melani WR, Zulfikar A. Effectiveness and efficiency of orthophosphatefitoremediation on detergent using kiambang $(P$. stratiotes) fitoremediation effectivity and efficiency of water lettuce $(P$. stratiotes) for detergent orthophosphate. S1 Program Study of Aquatic Resource Faculty of Marine Science and Fisheries, University Maritime Raja Ali Haji. 2013;1-8.

4. Dias V, Gomes AR. The fitoremediation approach for the control of hydric pollution. In Metal Ions in Biology and Medicine, 2016;9:437443.

5. Fonkou T, Agendia P, Kengne I, Akoa A, Nya J. Potentials of water lettuce (P. stratiotes) in domestic sewage treatment with macrophytic lagoon systems in Cameroon. International Symposium on Environmental Pollution Control and Waste Management. 2002;709-714.

6. Gupta R, Tripathi P, Kumar R, Sharma A, Mishra A. P. stratiotes
(Jalkumbhi). Pharmacognosy Reviews. 2010;4(8):153-160.

7. Harley KLS. Production of viable seeds by water lettuce, P. stratiotes L., in Australia. Aquatic Botany. 1990;36(3):277-279.

8. Hermawati E, Wiryanto W, Solichatun S. Phytemediation of Detergent Waste using Apu Wood (P. stratiotes L.) and Genjer (Limnocharisflava L.). Journal of Bio SMART. 2005;7(2):115-124.

9. Liu HW, He LY, Gao JM, Ma YB, Zhang XM, et al. Chemical constituents from the aquatic weed $P$. stratiotes. Chemistry of Natural Compounds. 2008;44(2):236-238.

10.Lu Q, He ZL, Graetz DA, Stoffella PJ, Yang X. Phytoremediation to remove nutrients and improve eutrophic storm waters using water lettuce (P. stratiotes L.). Environmental Science and Pollution Research. 2010;17(1):84-96.

11. Mbati G, Neuenschwander P. Biological control of three floating water weeds, Eichhorniacrassipes, P. stratiotes, and Salviniamolesta in the Republic of Congo. BioControl. 2005;50(4):635-645.

12. Mishima D, Kuniki M, Sei K, Soda S, Ike M, and Fujita M. Ethanol production from candidate energy crops: Water hyacinth (Eichhorniacrassipes) and water lettuce (P.stratiotes L.). Bioresource Technology. 2008;99(7):2495-2500.

13. Neuenschwander P, Julien MH, Center TD, Hill MP. P. stratiotes L. (Araceae). In Biological Control of Tropical Weeds Using Arthropods, 2009;332-352.

14. Odjegba VJ, Fasidi IO. Accumulation of trace elements by P. stratiotes: Implications for phytoremediation. Ecotoxicology. 2004;13(7):637646.

15. Pieterse AH. Experimental control of flowering in P. stratiotes L. Plant and Cell Physiology. 1978;19(6):1091-1093.

16. Prajapati SK, Meravi N, Singh S. Phytoremediation of Chromium and Cobalt using P. stratiotes: A Sustainable Approach. Proceedings of the International Academy of Ecology and Environmental Sciences.2012;2(2):136-138.

17. Rao PN, Reddy AS. Studies on the population biology of water lettuce: P. stratiotes L. Hydrobiologia, 1984;119(1):15-19.

18. Rodrigues ACD, do Amaral Sobrinho NMB, dos Santos FS, dos Santos AM, Pereira ACC, Lima, ESA. Biosorption of Toxic Metals by Water Lettuce (P. stratiotes) Biomass. Water, Air, and Soil Pollution. 2017;228(4):156

19. Šajna N, Haler M, Škornik S, Kaligarič M. Survival and expansion of P. stratiotes L. in a thermal stream in Slovenia. Aquatic Botany. 2007;87(1):75-79.

20.Sridhar MKC. Trace element composition of $P$. stratiotes $\mathrm{L}$. in a polluted lake in Nigeria. Hydrobiologia. 1986;131(3):273-276.

21. Tewari A, Singh R, Singh NK, Rai UN. Amelioration of municipal sludge by $P$. stratiotesL: Role of antioxidant enzymes in detoxification of metals. Bioresource Technology. 2008;99(18):8715-8721.

22.Ugya AY, Imam TS, Tahir SM. The Use of P. stratiotes To Remove Some Heavy Metals From Romi Stream: A Case Study Of Kaduna Refinery And Petrochemical Company Polluted Stream. IOSR Journal of Environmental Science, Toxicology and Food Technology (IOSRJESTFT), 2015;9(1):48-51.

23. Ingleby E. Research methods in education. Professional Development in Education.2012;38(3):507-509.

24.Pistia stratiotes L. EPPO Bulletin. 2017;47(3):537-543.

25.Dellinger RP, Levy MM, Carlet JM, Bion J, Parker MM, Jaeschke R, et al. Surviving sepsis campaign: International guidelines for management of severe sepsis and septic shock: 2008. Critical Care Medicine. 2008;36(1):296-327. 
26. Baron RM, Kenny DA. The moderator-mediator variable distinction in social psychological research: conceptual, strategic and statistical considerations. Journal of Personality and Social Psychology. 1986;51(6):1173-1182.

27.Zhu X, Wang JD, Solo-Gabriele HM, Fleming LE. A water quality modeling study of non-point sources at recreational marine beaches. Water Research. 2011;45(9):2985-2995.

28. Gerking SD. Fishery Biology: Past, Present and Future. Fisheries. 1988;13(1);1-56.

29. Vidali M. Bioremediation - An overview. Journal of Industrial Pollution Control. 2011;73(7).

30. Marinho-Soriano E, Nunes SO, Carneiro MAA, Pereira DC. Nutrients removal from aquaculture wastewater using the macroalgae Gracilaria birdiae. Biomass and Bioenergy. 2009;33(2):327-331.

31. Gujarathi NP, Haney BJ, Linden JC. Phytoremediation potential of Myriophyllum aquaticum and Pistia stratiotes to modify antibiotic growth promoters, tetracycline, and oxytetracycline, in aqueous wastewater systems. International Journal of Phytoremediation. 2005;7(2):99-112.

32. Kristensen E, Bouillon S, Dittmar T, Marchand C. Organic carbon dynamics in mangrove ecosystems: A review. Aquatic Botany. 2008;89(2):201-219.
33. Dellinger RP, Levy MM, Carlet JM, Bion J, Parker MM, Jaeschke R, et al. Surviving sepsis campaign: International guidelines for management of severe sepsis and septic shock: 2008. Critical Care Medicine. 2008;36(1):296-327.

34. Mbati G, Neuenschwander P. Biological control of three floating water weeds, Eichhornia crassipes, Pistia stratiotes, and Salviniamolesta in the Republic of Congo. BioControl. 2005;50(4):635-645.

35. Heim KE, Tagliaferro AR, Bobilya DJ. Flavonoid antioxidants: Chemistry, metabolism and structure-activity relationships. Journal of Nutritional Biochemistry. 2002;13(10):572-584.

36. Sharma N. Biologicals: Green Alternatives for Plant Disease Management. In Biological Controls for Preventing Food Deterioration: Strategies for Pre- and Postharvest Management. 2014:1-25.

37. Phillips SJ, Anderson RP, Schapire RE. Maximum entropy modeling of species geographic distributions. Ecological Modelling. 2006;190(34):231-259.

38. Gotelli NJ, Colwell RK. Quantifying biodiversity: Procedures and pitfalls in the measurement and comparison of species richness. Ecology Letters. 2001;4(4):379-391. 